\title{
Üniversite kampüs meydanlarında peyzaj tasarımı (İnönü Üniversitesi Kampüsü, Mediko Meydanı peyzaj tasarım projesi örneği)
}

\author{
Sima POUYA ${ }^{(D 1}$, Bülent YILMAZ ${ }^{(1}$ 1, Oğuz ATEŞ ${ }^{\circledR 1}$ \\ 1İnönü Üniversitesi, Güzel Sanatlar ve Tasarım Fakültesi, Peyzaj Mimarlığı Bölümü, Malatya
}

Alınış tarihi: 24 Haziran 2019, Kabul tarihi: 26 Kasım 2019

Sorumlu yazar: Sima POUYA, e-posta: sima.pouya@inonu.edu.tr

\section{Öz}

Üniversiteler birer eğitim kurumu olmalarının yanında önemli sosyal ve kültürel alanlar ve örnek mekânlardır. Üniversitelerdeki sosyal ve kültürel etkinlik alanları; farklı kültür, etnik ve sosyal yapılara sahip öğrencilerin eğitim süreçleri boyunca ders dışı zamanlarının büyük bölümünü geçirdikleri mekânlar olup, sosyal etkileşim açışından da büyük önem taşımaktadırlar. Dolaysıyla üniversiteler eğitim işlevleri için sürekli gelişmek, imkânlarını, kapalı alanlarını, alt yapılarını ve donanımlarını artırmak zorundadırlar. Ancak eğitime dönük yapılaşmanın yanı sıra dış mekân kullanımlarına dönük estetik ve fonksiyonel yapılanmayı da sağlamak zorundadırlar. İnönü Üniversitesi yakın zamanda kurulan üniversitelerden olmamasına rağmen, fiziki yapılaşması devam eden bir üniversitedir. Bu süreçte dış mekân peyzaj tasarım ve uygulamaları da önemli bir yer tutmaktadır. İnönü üniversitesi kampüsünde en merkezi ve meydan anlamında gelen Mediko meydanın hemen önünde yapılmakta olan camii nedeniyle bu meydana erişim ve yapısal anlamda değișimler görülmektedir. $\mathrm{Bu}$ alanda mekânlar arasında bağlantıyı yeniden oluşturmak ve alanın tüm kullanıcılar tarafından faydalanıla bilirliğini arttırmak için bir peyzaj tasarımına ihtiyaç duyulmuştur. Dolaysıyla İnönü Üniversitesi, Peyzaj mimarlığı bölümü proje III dersi kapsamında proje alanı olarak seçilen bu meydan, yeniden tasarım amacıyla değerlendirmeye alınmıştır. $\mathrm{Bu}$ amaca yönelik; problem tanımı, ihtiyaç listesinin belirlenmesi, alan analizi ve tasarım çalışması yapılmıştır. Bu çalışmanın sonucunda her öğrencinin tasarladığı ve geliştirdiği birer tasarım projesi ortaya çıkmıştır ve seçilen projelerden yararlanarak tasarım önerileri değerlendirilmiştir.

Anahtar kelimeler: Üniversite Kampüsü meydanı, Peyzaj tasarım projesi, İnönü üniversitesi kampüsü, Malatya

Landscape design at university campus (example of Inonu University Campus Medico Square Landscape design project)

\begin{abstract}
Universities are not only educational institutions but also important social and cultural areas. Universities as a social and cultural activity areas are places where students with different cultural, ethnic and social structures spend most of their extracurricular time during their education that it also has great importance in thier social interaction. Therefore, universities have to constantly develop their educational functions and increase their facilities, indoor areas, infrastructure and equipment. However, they must also provide aesthetic and functional structuring for outdoor use as well as educational building. Although İnönü University is not one of the recently established universities, its physical structure is still continuing. In this process, outdoor landscape design and applications have an important place. It is seen access and structural changes in the Mediko square as a main center and square of the İnönü University's campus due to the mosque which is being built just in front of the medico square. It was needed a landscape design to rebuild the connection between spaces in this area and to increase the usability to all users of the area.
\end{abstract}


Therefore, in Inonu University, Landscape Architecture department within the scope of project III, the mediko center as a chosen area were evaluated for re-design purposes. For this purpose; problem definition, determination of needs list, field analysis and design study. As a result of this study a design project developed and designed by each student andd esign proposals were evaluated by using selected projects.

Key words: University campus square, Landscape project design, Inonu university campus, Malatya

\section{Giriş}

Çevre tasarımı birçok fonksiyon, mekân niteliği, faktör ve ihtiyaç gibi konulara göre farklılık gösterir. Ayrıca mekânlarda kullanıcı ihtiyaçların karşılanması için yapılan tasarımlarda çeşitlilik gerektirirler. Üniversite kampüsleri kurumsal ve aktif mekânlar oldukları için çeșitli veriler yardımıla tasarlanmaları gerekir (Schmertz,1972; Coulson vd, 2017; Gie, 2008; Lau vd., 2014; Aydın ve Ter, 2008)

Bu mekânlarının tasarımında; çevresel karakterin korunması, mekânlar arasında iç mekân-dış mekân ilişkisinin, kentsel dokunun sürekliliğinin, ulaşılabilirliğin sağlanması, sembol oluşturma, resmiyet, algılanabilirlik, görsellik ve estetik gibi veriler dikkate alınmalıdır (Atabeyoğlu 2011 ve 2014). Yılmaz (1998)' e göre, Üniversite kampüslerinde açık ve yeşil alanların genelde bir park șeklinde planlanması, gerek öğretim elemanları ve gerekse öğrencilerin huzurlu bir ortamda bulunması açısından önemlidir ve bu durum eğitim ve öğretimin kalitesine genelde olumlu olarak yansır.

Altuğ (2004)'e göre; ülkemizde tercih edilen peyzaj uygulama teknikleri bașta ekonomik sorunlar olmak üzere çeşitli nedenlerden ötürü, kısa vadeli çözümler üreterek görsel kaliteyi düşürmekte, işlevsel olmayan mekânların yaratılmasının yanı sıra uzun vadede daha ciddi ekonomik sorunlar oluşturmaktadır. Bu anlayıș nedeniyle kent kimliğini oluşturmada, nitelik ve nicelik açısından yetersiz mekânlar, olumlu özelliklere sahip mekânlardan çok daha etkin olmakta ve sonuç olarak hem kent kimliği hem de kentin fiziksel gelişimi olumsuz yönde etkilenmektedir (Altuğ, Gülgün 2005; Atabeyoğlu 2014).

Üniversitelerde uzmanlık alanlarının çoğalması ve disiplinler arası ilișkinin gitgide yoğun olması üniversitelerin tüm bölümleriyle birlikte tasarlanmasını gerektirmiştir. Kent içinde yeterli alanın bulunmaması ve yapım maliyetlerin artırması gibi etkenlerden dolayı kent dışındaki üniversite kampüslerin yapılması tercih edilmiştir (Kuyrukçu, 2012). Kent dışı üniversiteler eğitim- öğretim ve araştırma işlevlerin dışında öğrenciler ve personel için gerekli hayat koşullarını (barınma, eğlence, alışveriş, spor, sağlık ve rekreasyon) sağlayan üniversite kentleridir (Şekil 1) (Türeyen, 2002; Çorbacı vd 2005).

Türkçe sözlügünde yerleşke anlamına gelen kampüs; eğitim merkezlerinin, öğrenci yurtlarının, öğretim elemanlarına ait lojmanların, sosyal tesislerin ve fonksiyonların birbirine bağlayan yolların, yürüme yollarının, açık yeşil alanların, rekreasyon alanların, spor alanların, alışveriş mekanların ve meydanların kapladığı çok işlevli bir eğitim alanıdır (Şekil 2) (Turner,1995; Sönmezler, 1995). Dober (2000)'e göre ise; üniversite kampüsleri, işlevsel yapıları gereği farklı fonksiyonları iç içe ya da yan yana kapsayan ve fiziksel açıdan büyüme eğiliminde olan eğitim alanlarıdır. Çalışma ve araștırma, barınma, dinlenme ve ulaşım gibi kentsel fonksiyonları daha küçük ölçekte kendilerinde barındırırlar. Kampüslerin farklı fonksiyonları kapsayan alanlardan oluşması ve bu fonksiyonlar arası ilişkilerin sürekliliğini devam ettirmesi için sistematik bir şekilde organize edilmesi gerektirmiştir (Erkman, 1990).

Kampüsü oluşturan bölgeler, içinde yer alan işlevlere (çalışma, dinlenme ve rekreasyon, barınma ve ulaşım) göre beş ana bölgede toplanmıştır. Bunlar; akademik bölge, idari bölge, dinlenme ve rekreasyon bölgesi, barınma bölgesi ve bunları birbirine bağlayan sirkülasyon ağıdır (Kuyrukçu, 2012).

Teknik servisler olarak bilinen bölüm de bu ana fonksiyonların konforunu artırmak için bulunmaktadır. Bununla birlikte, bazı örneklerde idari bölgenin akademik bölge içinde konumlandırıldığı da görülmektedir. Ayrıca, dinlenme ve rekreasyon bölgelerinin bazı alt bölgeleri içerdiği ve bunların birbirinden ayrı alt bölgeler halinde ele alındıkları örneklere de rastlanmaktadır (Kuyrukçu, 2012). Bu bölgelerin tanımları; Akademik Bölge, eğitim ve araştırma birimlerinin bulunduğu, genel olarak üniversitenin merkezini oluşturan ve kimlikli yapılarla tanımlanan bölgedir. Üniversitenin temel ișlevi olan öğrenim, öğretim ve araştırma faaliyetlerinin gerçekleştirildiği mekânlar topluluğundan oluşmaktadır ki bunlar; sınıflar, laboratuvarlar, araştırma merkezleri ve 
öğretim üyelerinin çalışma mekânları, hizmetli 25 odaları gibi mekânlarla örneklendirilmektedir (Bilgin, 2006; Erçevil ve Önal, 2011). Bu mekanların yüksekokul adı verilmekte ve akademik bölgede birden fazla fakülte veya yüksekokul bulunabilmektedir (Erçevik, 2008). birleștirilmeleri ile oluşan tesislere de fakülte veya

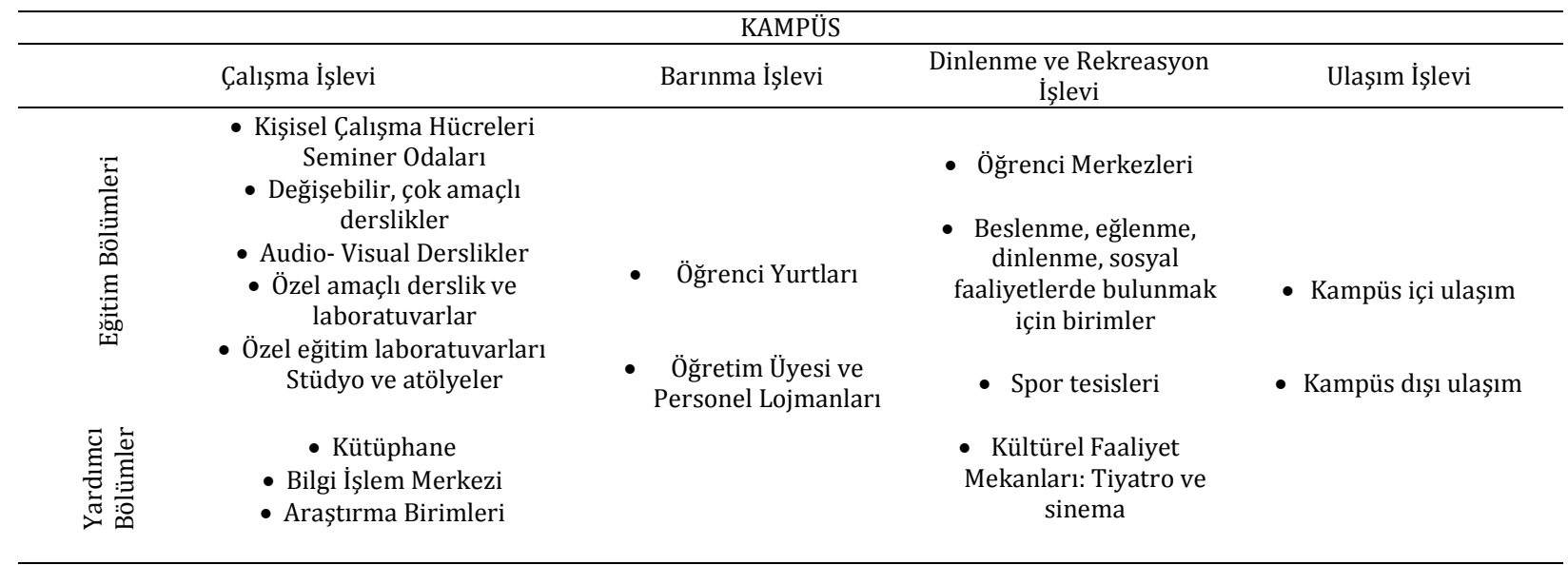

Şekil 1. Bir üniversite kampüsünün fonksiyonel içeriği (Öztürk, 2009; Erkman 1990).

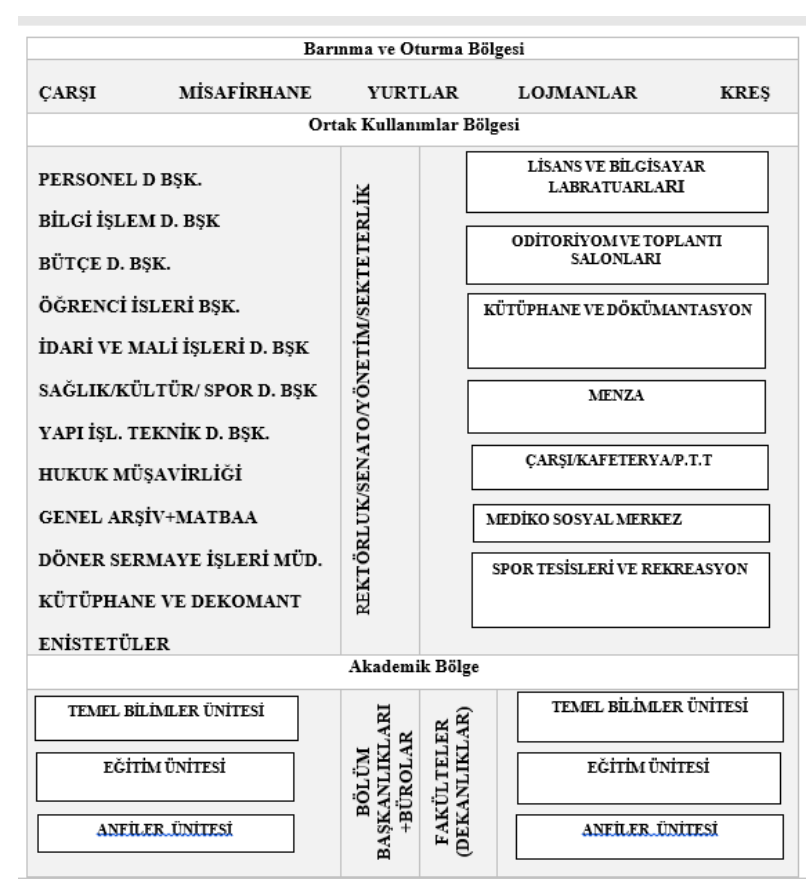

Şekil 2. Bir kampüsün organizasyonel yapısı (Çınar, 1998; Kurukçu, 2012).

Barınma bölgesi, yönetim, öğretim üyeleri, üniversite personellerinin ve öğrencilerin barınma ihtiyaçlarını karşılamak için lojmanlar, yurtlar ve ayrıca üniversitenin çeşitli etkinliklerine (kongre, konferans, sempozyum gibi) katılan misafirler için misafirhaneler sağlayan bir bölgedir (Bilgin, 2006). İdari bölge, rektörlük ve bağlı yönetim birimleri ile bazı durumlarda merkezi kütüphane, kongre ve konferans salonları, mediko-sosyal gibi birimlerin bulunduğu alandır. Genellikle kampüsün ana girişine yakın bir konumda yer alır ve kampüs için bir simgesel öğe niteliğindedir. Bazı kampüslerde dinlenme ve rekreasyon birimleri ile bütünleștirilerek, kampüs merkezi bölgesini oluştururlar (Erçevik, 2008). Yönetim bölgesi, rektörlük, oditoryum, kütüphane ve konferans salonunu bir araya getirir, bu yapılar farklı bölgelerde planlayabilir ancak yönetim yapıları vurgulanmalıdır (Bilgin, 2006). Bu binaların çevresinde büyük kapasiteli otoparka mutlaka yer vermelidir (Çınar, 1998).

Kampüsteki sportif, sosyal ve kültürel tesisler gibi ortak kullanım alanları dinlenme ve rekreasyon bölgesinde yer almaktadır. Bu bölgede yer alan aktiviteler sayesinde öğrenci- öğrenci ve öğrenciöğretim üyesi ilișkileri sosyo-kültürel yönden gelişmektedir.

Bir kampüsün ortak kullanım alanları dinlenme ve rekreasyon bölgesinde yer almaktadır. Sosyal ve kültürel bir alışveriş ortamı oluşturarak, çeşitli yörelerden ve farklı yaşam tarzına ve kültüre sahip öğrencilerin kültür birliği oluşturmalarını yaratmaktadır (Özer, 2008). Bu mekânlar, bütününü zenginleștirmek için bazen bir meydan, bazen bir heykel, süs havuzu ya da saat kulesi gibi simgeler kullanarak meydan ve toplama alanı yaratmaktadır (Bilgin, 2006).

Ulaşım bölgesi, üniversite kampüslerinde yer alan çeșitli kullanımların birbirleri ve kent ile olan ilişskilerini sağlamak için kampüs tasarımlarında 
önemli bir yere sahiptir. Yayaların rahat ve güvenliği açısından, kentsel alanlar gibi yaya ile motorlu araç ulaşımının birbirlerinden ayrı ve birbirlerini kesmeyecek şekilde planlamaları gerekmektedir (Karaaslan, 1979; Kuyrukçu, 2012). Kampüslerde çok çeşitli kullanıcının bulunması, kampüslerde kompleks yapılar ortaya koymaktadır. Bunlar arasındaki bağlantı ise yaya ve taşıt akslarıyla sağlanmaktadır (Turcan, 1996). Teknik servisler, teknik olarak isitma merkezi, trafo, garaj, marangozhane, su depoları gibi birçok bölüm öncelikler ve ekonomi bazında incelenerek kampüs içinde düşünülebilir. Burada mimari tasarım açısından önemli olan nokta; bu dağıtım ve toplama şebekelerinin kullanıcılardan mümkün olduğu ölçüde gizlenmesi gerekmektedir. Ancak arıza, bakım, yenileme gibi müdahale gerektiren durumlarda bu şebekelere en kolay yoldan ulaşıllarak rahat bir ortamda çalışma yapılabilmelidir (Çınar, 1998; Kuyrukçu, 2012).

Kampüslerde meydana gelen bazı değişmeler sayesinde fiziksel büyüme ortaya çıkmaktadır. Örneğin öğrenci sayısının zaman içerisinde artması, bilim dallarındaki gelişmeler ile bazı yeni fakülte veya bölümlerin kurulması, kampüslerin büyüyebilir olarak tasarlanmasını gerekli kılmaktadır (Karaaslan, 1979; Erkman, 1990).

İnönü Üniversitesi yakın zamanda kurulan üniversitelerden olmamasına rağmen, fiziki yapılaşması devam eden bir üniversitedir. Bu süreçte dış mekân peyzaj tasarım ve uygulamaları da önemli bir yer tutmaktadır. İnönü üniversitesi kampüsünün en merkezi ve en çok kullanıcının yararlandığı meydanı olan mediko meydanı, yapılmakta olan camii nedeniyle değişmektedir. Bu alanda mekânlar arasında bağlantıyı oluşturmak ve alanın tüm kullanıcılar tarafından faydalanılabilirliğini arttırmak için yeniden bir peyzaj tasarımına ihtiyaç duyulmuştur. Dolaysıyla Peyzaj mimarlığı bölümü Proje III dersi kapsamında proje alanı olarak seçilen bu meydan yeniden tasarım amaciyla değerlendirmeye alınmıştır. Alanı yeniden tasarlaması için alan analizi ve kullanıcılara anket ve görüşme çalışması yapılmıştır.

\section{Materyal ve Metot}

\section{İnönü Üniversitesi}

İnönü üniversitesi 1975 yılında Malatya ili karakavak mahallesinde eğitim vermeye başlamış ve 1984 yılında Elazığ yolu 8. Km'de bulunan 7000 dekarlık alana taşımıştır (URL 1).
Bugün 14 fakülte ve 1 konservatuar Müdürlüğü, 1 yüksekokul, 5 Enstitü, 1 Teknokent ve 1 Tömer ile eğitim hizmetlerini sürdüren üniversitenin çok amaçlı kültür salonları, sosyal tesisleri ve lojmanları bulunmaktadır. Üniversitenin toplam öğrenci sayısı 42.760, akademik personel 1177 ve idari personel sayısı ise daimi 1063 geçici 234 personel ile toplam 1297 çalışan bulunmaktadır (URL 1). Üniversite içerisindeki 250 lojman ve 14 Bloklu Toplu konutlarda yaklaşık 4000 kişi ikamet etmektedir. Yerleşke içerisinde öğrencilere barınma imkanı sağlayan 3 tane yurt bulunmaktadır. Üniversiteye gelen akademik ve idari misafirlerin ağırlandığ toplamda 39 kişilik kapasiteli üniversite konukevi bulunmaktadır. Bunun dıșında 68 odalı hastane oteli ve 200 yataklı hasta ve yakınları konukevi bulunmaktadır. Üniversite yerleşkesi çevre yolu üzerinde yer aldığından gerek şehir içinden gerekse şehir dışından gelenler için kolay bir ulaşım noktasidir (URL 1).

\section{Mediko sosyal tesisleri}

İnönü üniversitesinde merkez kampüste bulunan Mediko Sosyal Tesisleri 1984 yllında kurulmuștur. Yılın 12 ayı aktif olan bu alan özellikle kayıt dönemleri ve burs alma dönemlerinde ekstra yoğun olmaktadır.

2 katlı Mediko Sosyal Tesisleri; bünyesinde 3 yemekhanesi, 1116 kișilik kapasitesiyle 3000 metrekarelik bir alanda bulunmaktadır. Bina içerisinde bir erkek kuaförü, 1 sağllk merkezi, 2 banka şubesi, bina dıșında ise 7 banka ATM'si bulunmaktadır. Yemek kartı çıkartmak için bir birim ve kartlara para yükleyebilmek için 3 adet kyox cihazı bulunmaktadır. Giriș katta 5 adet masa tenisi bulunmaktadır. Sağlık kültür daire bașkanlığı burada hizmet vermektedir. Bina içerisinde bulunan 23 adet ofisin 5 tanesi fotoğrafçllık, tiyatro, bisiklet, okçuluk ve dağcllı öğrenci toplulukları bulunmaktadır. Geriye kalan 83 öğrenci topluluğu tek bir ofisten idare edilmektedir (URL 1).

Çalışmanın materyalini Malatya kentinde kurulu bulunan İnönü Üniversitesi kampüsü içerisinde yer alan, Mediko meydanı oluşturmaktadır. Proje alanı, kampüsün merkezinde bulunan Mediko meydanın hemen önünde yapılmakta olan camii nedeniyle erişim ve yapıssal anlamında değişmektedir (Şekil 3). $\mathrm{Bu}$ alanda mekanlar arasında bağlantıyı yeniden oluşturmak ve alanın tüm kullanıcılar için faydalanıla bilirliğini arttırmak amacıyla yeniden peyzaj tasarımına ihtiyaç duyulmuştur. Dolaysıyla Güzel Sanatlar ve Tasarım Fakültesi, Peyzaj 
Mimarlığı Bölümü 3 sınıf Proje III dersi kapsamında proje alanı olarak seçilen bu meydan yeniden tasarım amacıyla değerlendirmeye alınmıştır.

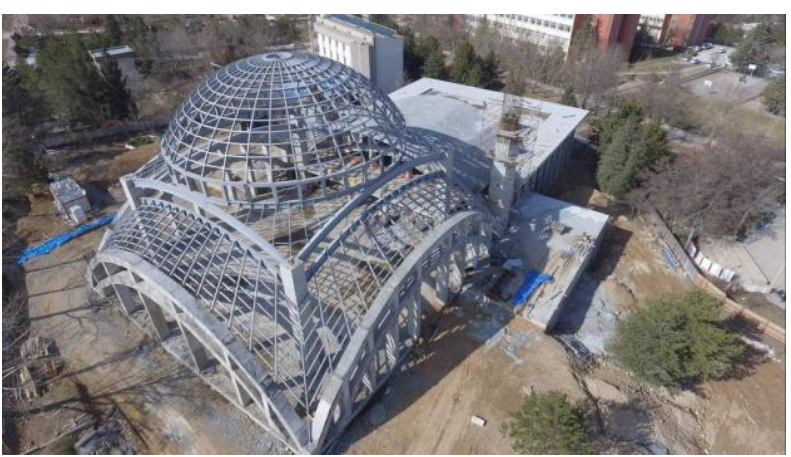

Şekil 3. Proje alanında yapılması devam eden üniversite camisi

Çalışma alanına ait toprak analizlerinden, alanın tamamının kahverengi toprak olduğu tespit edilmiştir. Kahverenkli topraklar, çernozyemlerle çöl toprakları arasında yer almaktadır. Çalışma alanının iklimi karasaldır; yazlar sıcak ve kurak, kışlar soğuk ve çoğu kez kar yağışlıdır. Ancak son yıllarda yapılan Karakaya ve diğer baraj göllerinin etkisiyle, iklim yumuşayarak zaman zaman Akdeniz iklimi özelliklerini göstermektedir. En çok yağıș, ilkbahar ve sonbahar aylarında görülmektedir. Fırat Havzasında yer alan Malatya, kışları yağışlı ve soğuk, yazları sıcak ve kurak bir iklime sahiptir. İlde yağışın bir kısmı kar, bir kısmı da yağmur şeklinde olmaktadır. Malatya'nın iklimi aslında karasal ile Akdeniz iklimi arasında bir mikro klimadır. Yıllık yağışın büyük kısmı kış, ilkbahar ve sonbaharda yağmaktadır. Malatya, yaz aylarında çok az yağış almaktadır. Malatya toprakları önemli bitki örtüsünden yoksundur. Doğal şartlar ormanların kendi kendisini yenilemesini büyük ölçüde güçleştirdiğinden yer yer bozkırlar ortaya çıkmıștır. Çoğu bozuk nitelikli olmak üzere, meşenin çoğunlukta olduğu yapraklı ormanlar vardır (Ateș ve Sabaz, 2013).

\section{Metot}

$\mathrm{Bu}$ çalışmadan amacı, elde edilen veriler ve ihtiyaç programı doğrultusunda, farklı sirkülasyon ve mekanların bulunduğu tasarım önerilerin geliştirilmesidir. Bu amaca yönelik; problem tanımı, ihtiyaç listesinin belirlenmesi, alan analizi ve tasarım çalışması yapılmıştır. Proje III dersi kapsamında yapılan bu çalışmanın sonucunda her öğrencinin tasarladığı ve geliștirdiği birer tasarım projesi ortaya çıkmıştır. Seçilen projelerden yararlanarak tasarım önerileri değerlendirilmiştir.

Problem tanımı aşamasında proje alanında, kampüsün merkezinde bulunan Mediko meydanın hemen önünde inșa aşamasında bulunan camii nedeniyle bu meydana erişim ve yapısal anlamda değişmesi problem olarak belirlenmiştir. $\mathrm{Bu}$ alanda mekânlar arasında bağlantıyı yeniden oluşturmak ve alanın tüm kullanıcılar tarafından faydalanılabilirliğini arttırmak için bir peyzaj tasarımına ihtiyaç duyulmuştur. Dolaysıyla İnönü Üniversitesi, Peyzaj mimarlığı bölümü proje III dersi kapsamında proje alanı olarak seçilen bu meydan yeniden tasarım amacıyla değerlendirmeye alınmıştır.

İhtiyaç listesinin belirlenmesi aşamasında bu alandaki kullanıcılarının (öğrenciler, akademisyenler ve idari personel) ihtiyaç ve istekleri belirlenmiştir. İhtiyaç listesinin hazırlanması için alandaki kullanıcılara, meydanın çevresinde bulunan baka ve sosyal tesisin personeline ve öğrencilerle görüşme yapılmıştır. 156 kişi ile yapılan görüşme sonuçlarına göre kullanıcıların ihtiyaçları sırasıyla, oturma ve dinlenme alanları, otopark alanları, spor alanları, yemek yeme alanları, satış birimleri, kitap okuma açık yeşil alanları, amfi tiyatro, sergi alanı ve şenlik ve toplanma alanları olarak belirlenmiştir.

Alan analizi aşamasında alanla ilgili bilgi toplanmış, sörvey ve değerlendirmeler gerçekleştirilmiş, alandan fotoğraflar çekilmiştir. Mediko meydanın hemen doğu kısımda 2 katlı Mediko sosyal binası yer almaktadır. Bina dışındaki merkezi alan, dış mekân kullanımları için ayrılmıştır. Mevcut şekliyle alan uzun zaman önce yapılmış, kampüsün merkezindeki önemli toplanma, dinlenme ve geçiş alanlardan birisidir. Alan içerisinde yaklaşık $2.500 \mathrm{~m}^{2}$ alana sahip, meydan olarak kullanılan çok fonksiyonlu, kare bir beton zemin bulunmaktadır. Meydanın kuzeyinde 3 adet spor sahası, batısında yapılması hala devam eden $4.700 \mathrm{~m}^{2}$ üniversite camisi yer almaktadır. Bu meydan aynı zamanda üniversitenin 2 ana yolunu birbirine bağlayan bir alandır. Bu iki yolun arasındaki 10m kadar kot farkından dolayı alana giriş ve çıkışlar merdivenler ile çözülmüştür. $\mathrm{Bu}$ yolların birisi alanın güney kısmında ve yüksek kotta bulunduğundan dolay yaklaşık 30 merdivenle alana bağlanmaktadır. Diğer yol ise meydanın kuzey kısmındaki İnternet Merkezi binası içinden geçerek pembe yola bağlanmaktadır. Meydana giren diğer yol ise batı kısmında, gölgeli büyük çınar ağaçlarıyla çevirili olan bu yol genelde Fen Edebiyat Fakültesi 
yönünden alana girmek isteyen bireyler tarafindan kullanılmaktadır (Şekil 4).

Proje alanında 2 adet otopark alanı mevcuttur bunlardan birisi 50 araç kapasitesi olan ve alanın güney kısmında, giriş yolun sağında bulunmaktadır. Diğeri ise caminin hemen batısında bulunan üniversite konukevine aittir. Mediko sosyal binasının arkasında olan Kıbrıs Meydanı yaklaşık $3.200 \mathrm{~m}^{2}$ dikdörtgen beton alandır ki sadece yıllık şenlik ve tören zamanlarında değerlendirmektedir. Alanda yer alan tören alanı, otopark ve spor sahası gibi pek çok özelliği yüklendiği için fonksiyonları sağlıklı bir şekilde yerine getirememekte, alanın prestijine uymamakta, hem de estetik olarak hoş olmayan bir görüntü ortaya koymaktadır. Alan genelinde münferit ve gelişi güzel bir bitkilendirme anlayıșı mevcuttur. Alanda kuzeyden güneye doğru yükseklik artmakta ve bazı geçiş yolları eğimli ve düzensiz kullanılmaktadır.

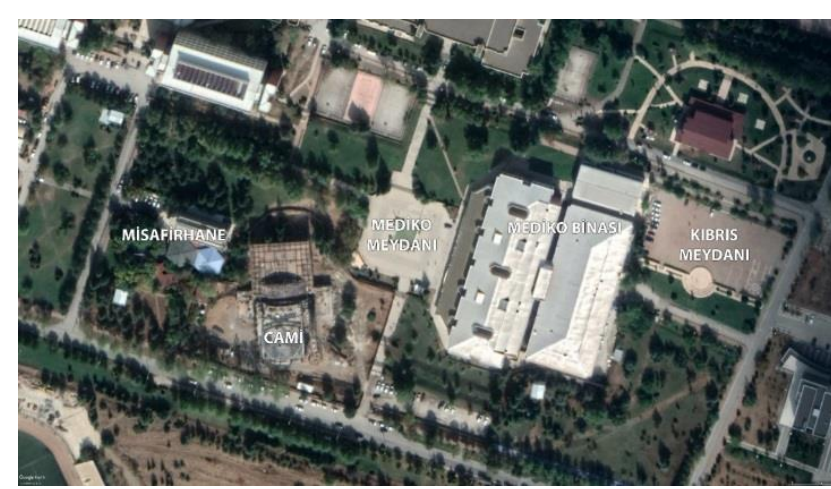

Şekil 4. Proje alanına ait mevcut durum planı

\section{Bulgular ve Tartışma \\ Tasarım Önerileri}

\section{Park alanları}

Mevcut 50 araçlık ve 10 araçlık otoparklar bulunmaktadır. Ancak yapilan anketler ve alanda gözlemlere göre bulunan bu otopark alanları kullanıcılar için (öğrenci ve üniversite personeli) yetersiz kalmaktadır ve caminin ileride tamamlanmasıyla camiye girmek amaciyla otopark alanlarına ihtiyaç duyulacak olan kullanıcı sayısı çoğalacaktır. $\mathrm{Bu}$ nedenle yapılan tasarım önerilerinde otopark yetersizliği sorunu çözülmeğe çalışılmıştır.

Alandaki mevcut bitkilerin korunmasını önemseyen bu önerilerde otopark alanları, kullanılmayan veya elverişlisini yitiren sert beton zeminlerde ve ayrıca ulaşllabilecek en uygun olan yerlerde önerilmiştir. $\mathrm{Bu}$ alanlardan birisi alanın güney girișinin sağ kısmında mevcutta otopark olarak kullanılmakta olan alandır. Tasarım önerilerinde bu otopark alanın yeniden düzenlenmesi ve araç park kapasitesinin artırılması önerilmiştir (Şekil 5). Yaklaşık olarak bu alanda 30 araçlık otopark tasarlanmıştır. Ancak bu alan yetersiz kaldığı için alanın diğer yerlerinde otopark önerisi getirilmiştir. Bunlardan birisi alanın doğu kısmında bulunan Kıbrıs meydanıdır. Bu alan sert beton zemine sahip olduğundan ayrıca yılda birkaç kez şenlik alanı olarak kullanım dışından başka hiçbir fonksiyonu olmadığı için şenlik dışındaki zamanlarda otopark alanı olarak tasarlanmıștır (Şekil 6). Kıbrıs meydanında tasarlanan otopark alanı yaklaşık 200 araçlık kapasitelidir.

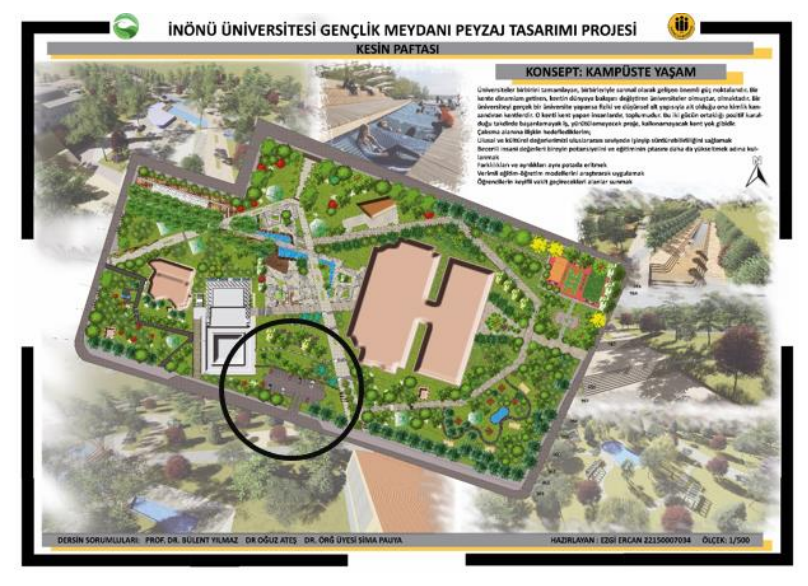

Şekil 5. Yeniden düzenlenen giriş otoparkı fikrinin yer aldığı proje örneği (Ezgi ERCAN).

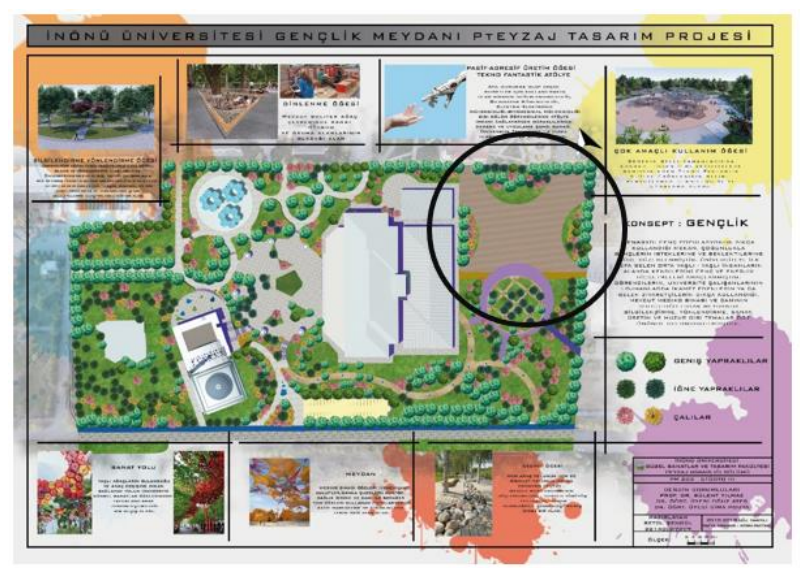

Şekil 6. Hem şenlik alanı hem de otopark olarak tasarlanan Kıbrıs meydanı örneği (Betül ŞENGÜL)

Tasarımlarda otopark alanı olarak önerilen diğer alan ise alanın kuzey batısında bulunan spor sahaların yerine önerilmiştir. Voleybol sahası olarak kullanan bu alanların yerine otopark önerilmesinin nedeni üniversitenin Spor Bilimleri Fakültesi 
çevresinde ve çalışma alanına 500m mesafede spor alanlarının bulunmasıdır. Ayrıca analiz aşamasında yapılan anketlere göre bu alandan çıkan ses gürültüsü alanda bulunan veya geçen diğer kullanıcıları rahatsız etmektedir. Yaklaşık 100 araçlık bu otopark alanı, çalışma alanını kullanmak isteyenlere hizmet verebilecektir. Bazl tasarım önerilerde ise kuzeydeki yolun kot farkından $(10 \mathrm{~m}$ kot farkı) yararlanıp bu mevcut spor alanın yeraltı kısmını otopark olarak tasarlanmışlar böylece alanın üst kısmı başka fonksiyonları için ayrılmıştır (Şekil 6).

Proje alanında mevcut olan diğer otopark ise alanın güney batısında bulunan üniversite konukevinin hemen yanında bulunan otoparktır. $\mathrm{Bu}$ otopark genelde konukevine gitmek isteyen bireyler tarafından kullanılmaktadır. Proje tasarım önerilerinde genelde bu alan aynı konumda fakat biraz daha düzenlenerek tasarlanmıștır (Şekil 7).

Tasarlanan park yerlerinde engelliler için de en az 1 tane olmak üzere yeterli sayıda elverişli park ve inme/binme yerleri ayrılmıştır. Engelliler için ayrılmış park yerleri, engelli işareti ile belirlenmiştir ve engelli park işaretleri görülür, okunur ve ișıklı olmuștur.

\section{Sirkülasyon sistemi}

Proje alanı tasarımında en çok önem verilen konulardan birisi alandaki mevcut veya tasarlanan fonksiyonlar arasındaki bağlantının ve sirkülasyonun özellikle engelli bireyleri göz önüne alınarak sağlanmasıdır. Tüm yayaların rahatça hareket edebilmeleri için yaya kaldırımı genişliği en az $150 \mathrm{~cm}$ olmuştur. Ayrıca mediko meydanı bir kültür ve buluşma meydan olarak önemli rol almasının yanında aynı zamanda etraftaki diğer fakülteler ve fonksiyonlara erişim amacıyla kullanılan bir merkezi geçiş yoludur. Var olan güneyden kuzeye ve Mediko meydanından geçerek sonra mühendislik fakültesi altından geçen ve pembe yolunan bağlanan yol, proje alanındaki en kullanışlı ve önemli bağlantı olarak sayılmıştır. Trambüs durağının tam önünde bulunan bu yol birçok öğrencinin her gün kullandığı geçiş yolu olarak gözlemlenmiştir. $\mathrm{Bu}$ proje kapsamındaki birçok tasarımlarda bu yolun düzenlenmesi; yolun genişletilmesi, görsel anlamda yolun etrafında su ve çiçek donatılarıyla güzelleștirilmesi ve engelli rampaların eklenmesi önerilmiştir. Merdiven ve rampa başlangıç/ bitişlerinde görme engelliler için yer işaretlemeleri yapılmıştır. Ayrıca yolun solunda yapılmakta olan camiye bağlantının bu yoldan sağlanması yapılmıştır.

Projelerdeki işlevini korunan ancak bazı düzenlemeler önerilen diğer yol ise Mediko meydanın batısında bulunan ve yol boyunca görkemli çınar ağaçlarıyla çevrilmiş olan yoldur. Bu yol Konukevi ve Fen Edebiyat Fakültesi'nden meydana bağlantı sağlamaktadır. Birçok öğrencinin tercih ettiği bir yoldur. Mediko meydanına acil durumlarda protokol araç girişi sağlamak için bu yolun genişliği göz önüne alınarak yeniden tasarlanmıştır. Bu yolun mevcut haline bakıldığında yolun etrafındaki fonksiyonlara (yolun altında fenedebiyat fakültesi ve yolun üstündeki açlk cim alanları) herhangi bir geçiş düşünülmediği için kullanıcılar kendileri bazı topraklı geçişleri yaratmışlardır bu nedenle önerilen düzenlemelerden birisi bu yoldan diğer yan alanlara geçiş sağlanmasıdır.

Alanda tasarlanan bütün fonksiyonların arasındaki ikinci ve üçüncü dereceden geçişler sağlamaya çalışılmıştır ancak buradaki dikkat edilmesi gereken nokta gereksiz ve alanlara parçalanmaya sebep olan geçişlerden uzak durması olmuştur (Şekil 9 ve 10).

İnşaatı devam eden camiye bağlantı yolları tasarlamak bu projedeki en önemli tasarım konusu olmuştur. Cami projesinde planlan bağlantı yolu, alanın güneyindeki yolunun tam giriş kısmından olmuştur bu yol ana cadde kotuyla aynı olup ve engelli bireylere rahatlıkla camiye ulaşım sağlamaktadır. Bazı tasarım önerilerde bu yol caminin arka kısmına kadar devam edip arkada tasarlanan cami avlusunun bağlanmıştır. Cami ve Mediko meydanın arasındaki yaklaşık 7 metrelik kot farkı nedeniyle Mediko meydanından camiye verilen bağlantı ancak merdiven yoluyla çözülmüştür. Camiye, Mediko meydanından ulaşmak isteyen kullanıcıların yorulmasının engellenmesi için genelde her 10 merdiven arası sahanlıklar tasarlanmıştır (Şekil 7, 8 ve 9). Basamak yüksekliği maksimum $15 \mathrm{~cm}$, basamak genişliği ise en az $30 \mathrm{~cm}$ olmuştur. Merdivende yer alan basamak gruplarında, basamaklar arasında yükseklik farkı olmamış, bütün basamaklar eșit yükseklikte tasarlanmıştır. 300 cm' den daha geniş olan merdivenlerin ortasında ilave tırabzan yapılmıştır.

Camiinin planında, camı yapının kuzey kısmında dükkanlar planlanmıştır bu dükkanlara giriş sağlamak amacıyla genelde alanın batı kısmında çınar ağaçlarıyla çevreleyen yoldan geçişler tasarlanmıştır. Mediko meyanından Mediko tesisinin 
arka kısmına gitmek isteyen kullanıcılara ise Mediko binanın kuzey ve güney kısmından geçişler tasarlanmıştır bu geçişler bazı projelerde tasarlanan fonksiyonların içinden geçerek binanın arkasına bağlanmıştır. Mediko tesisin arkasında bulunan depo girişine araçların girmesini sağlayan yol ise Kıbrıs meydanın alt kısmından alanın doğudaki yoldan sağlamaya çalıșılmıştır. Bazı önerilerde ise bu araç yolu Kıbrıs meydanın kuzeyindeki yoldan tasarlanmıştır (Şekil 5, 6 ve 7).

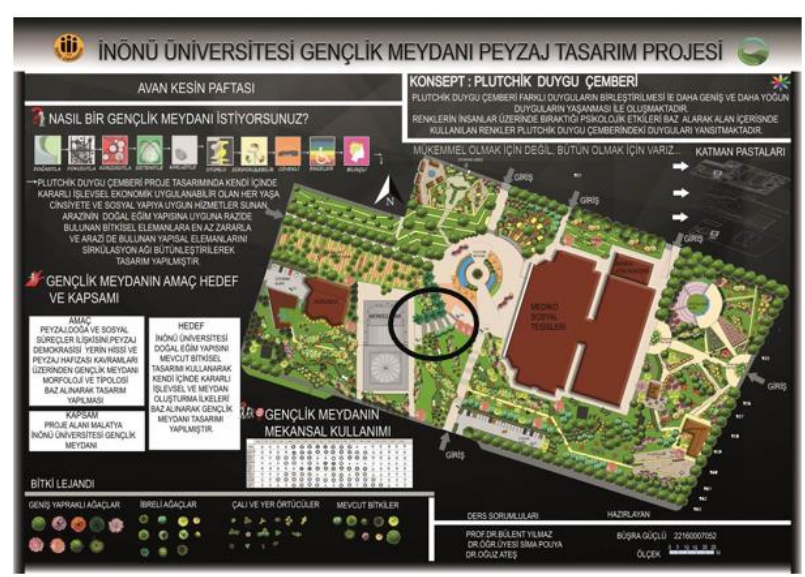

Şekil 7. Mediko meydanı ve camiye sağlanan bağlantı önerisi (Büşra Üçlü).

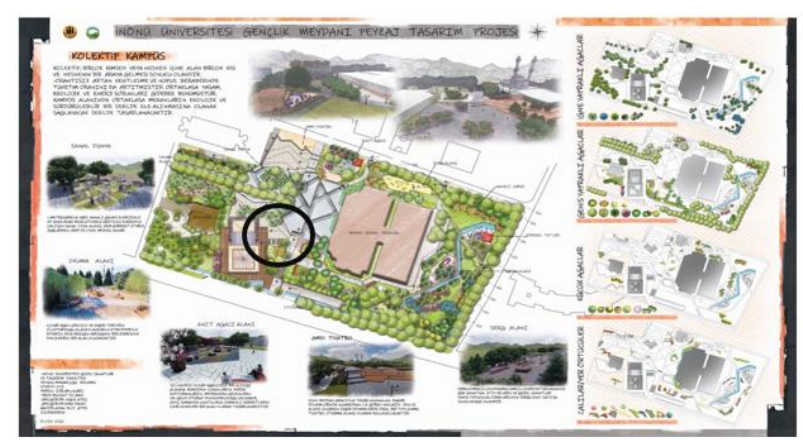

Şekil 8. Mediko meydanı ve camiye sağlanan bağlantı önerisi (Filiz Ateş).

\section{Mediko Meydanı}

Mediko meydanı İnönü üniversitesi kampüs meydanı olarak önemli yere sahiptir. Bu meydan mevcut haliyle birçok işlev ve fonksiyonlara ev sahipliği yapmaktadır. Bu işlevlerden en önemlisi toplanma ve buluşma alanı, dinlenme ve oturma alanı, diğer mekânlara geçiş sağlayan bir meydan ve üniversite tanıtım toplulukların aktivite alanı olarak sayılmaktadır. Alan analiz çalışmasında öğrenci ve personellere yapılan anketlere göre kullanıcı memnuniyet oranı bu alanda az olup ve bu yüzden tasarım proje kapsamında en çok değişiğe sahip olan alan olmuştur.

Mediko meydanın üniversiteyi temsil eden en önemli merkez konumundan dolayı proje kapsamında önerilen tasarımlarda, meydanın işlevselliği yanında estetiğine de önem verilmiştir. Estetiği sağlamak için farklı tasarım biçimleri, süs havuzu, seçilen bitki türleri ve kullanılan döşeme ve donatı elemanlarıyla sağlamaya çalıșılmıștır. Projelerde meydanın formunu en çok etkileyen konu ise camiye bağlantı sağlayan merdivenlerin tasarımı olmuştur. Tasarlanan formlar, meydanı temsil eden kare ve daire biçimi olmakla beraber bazı projelerde üçgen ve oval biçimler de önerilmiştir (Şekil 5, 6, 7, 8 ve 9). Meydandaki fonksiyonların artırması ve rahatlıkla kullanılması için genellikle etraftaki yolları meydan alanına katarak bu alanın genişlenmesi sağlanmıştır (Şekil 8). Bazı projelerde ise meydanın kuzey batısında bulunan ve mevcutta spor alanı olarak kullanın alanı tamamen Mediko meydanına birleştirip böylece bu alanın daha da büyütülmesine neden olmuştur. Meydanın estetiğini artırmak için alanın biçimine uygun sus havuzları tasarlanmıştır bunun yanında sert beton alanı kırmak için ve gölgeli alanlar yaratmak için kullanıcıların geçişlerini engellemeyecek şekilde gölgeli ağaçlar ve çiçek parterleri tasarlanmıştır. Mediko binasında çalışan personel ve öğrenciler için meydanda oturma ve dinleme alanları düşünülmüştür. Bazı projelerde cami ve meydan arasındaki kot farkından yararlanıp amfitiyatro tasarlanmıştır.

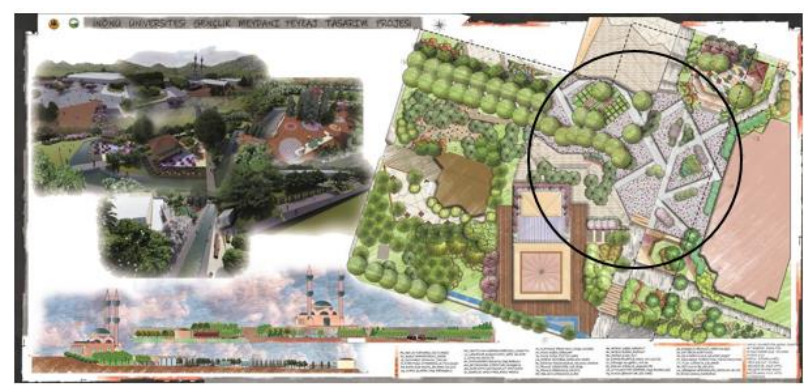

Şekil 9. Mediko meydanın genişletilmesi ve yeniden biçimlendirmesi (Filiz Ateş).

\section{Amfitiyatrolar}

Üniversite tarafından yılda kaç kez yapılan şenlik ve törenler için projelerde tören alanına yer verilmiştir. Bazı projelerde Kıbris meydanı yeniden düzenlenerek şenlik alanı olarak işlevine devam ettirmesi önerilmiştir ancak bu alan yılda yapılan birkaç kez şenlik dışında yıllın diğer zamanlar işlevsiz kalmıștır (Şekil 8). 0 yüzden alan içerisinde 
rekreaktif bölgede, yıllık gösteriler, müzik dinletileri, toplantılar, öğrencilerle yapılacak dersler, bahar şenliklerinde stantların kurulması vb. etkinlikler için kullanabilecek alan olacaktır.

\section{Camii avlusu ve bahçesi}

Camiye ait bir bahçe ve oturma alanı olarak tasarlanan bazı tasarım önerileri projelerde verilmiştir. $\mathrm{Bu}$ alan camiye girmek isteyen veya bekleyen bireyler için hizmet vermek için tasarlanmiştır ve alan genelde caminin kuzey kısmında dükkânların bulunduğu alanda veya camının batı kısmında ağaçlık alanın içinde düşünülmüştür. $\mathrm{Bu}$ alanda süs havuzu, gölgeli ağaçlar ve mevsimsel çiçekler tasarlanarak estetiğine yer verilmiştir.

\section{Satış birimler}

Satış birimleri; kampüs kullanıcılarının, ziyaretçilerin ve özellikle öğrencilerin ihtiyaç duyabilecekleri her türlü gıda, gazete, dergi, kitap, giysi, üniversiteyi tanıtıcı eşyalar vb. ürünlerin satışının yapılabileceği birimler olarak tasarlanmıştır. Ayrıca sanatsal ürünler, Malatya'ya özgü hediyelik eşya ve buna benzer satış mağazaları önerilmiştir. Kıbrıs meydanı işlevsiz sert beton zemine sahip olduğu için alışveriş dükkanları için müsait alan olarak seçilmiştir. Bazı projelerde ise bu alanın kuzeyinden geçen yolun alt kotta bulunmasından yararlanıp istinat duvarı yerine Kıbrıs meydanın altında alışveriş dükkanları tasarlanmıştır. (Şekil 10).

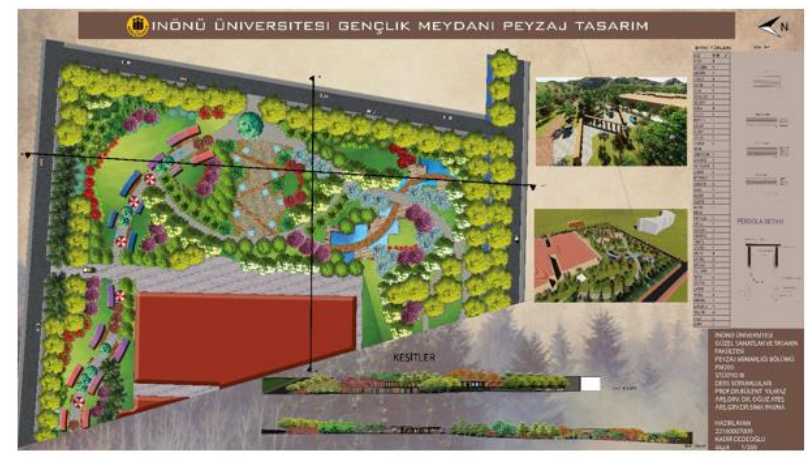

Şekil 10. Mevcut Kıbrıs meydanın yerine satış birimlerin tasarlanması (Kadir Dedeoğlu)

\section{Spor alanları}

Üniversitenin hemen hemen tüm spor branşlarını bünyesinde barındıran spor kompleksinin proje alanıyla arasında $500 \mathrm{~m}$ mesafe olduğu için, öğrencilerin spor ihtiyaçlarını bu alanda karşılaması gerektiği düşünülmüştür. Çalışma alanının kuzey batısında, Fen- Edebiyat fakültesinin hemen yanında bulunan voleybol ve futbol sahalarının bazı projelerde ayni işlevinin devam ettirilmesi önerilmiştir. Kıbrıs meydanının bulunduğu alanda küçük çaplı spor alanlarının tasarlandığı projelerde görülmüştür.

\section{Sergi alanı, sanat sokağı}

Projelerin çoğunda sanat atölyesi ve sanat sokağ tasarlanmıştır. Kıbrıs meydanında (sert beton zeminde) sanat atölyesi önerilmiştir. Bu atölyelerde öğrenciler boş zamanlarında sanatsal aktivitelere (resim, müzik, el sanatlar vb) katılabilirler ve böylece sanat seven öğrencileri bir araya gelmelerine sebep olup ve onların gelişmeleri ve zevkli zaman geçirmelerini sağlayabilir. Ayrıca ürettikleri sanat eserleri sanat sokağı denilen alanda sergilenebilir. Sanat sokağın yeri ise Mediko binasının üst yolundan geçen yol (Kıbrıs meydanından Mediko meydanına geçen yol) boyunca tasarlanmıştır. Ziyaretçiler bu yoldan geçerek sanat eserlerini ziyaret edebilirler. Sanat eserlerini sergileyen öğrenciler Güzel Sanatlar ve Tasarım Fakültesi öğrencileri de olabilir.

\section{Bitkilendirme}

Proje alanında mevcut bitkilerin tür ve sayısı alan analiz çalışmalarında çıkarılmıştır. Bu bilgiler proje taslak paftasına işlenerek mevcut bitkilerin yok edilmemesine özen gösterilmiştir. Bu konu proje üstünde çalışan öğrenciler için en çok kısıtlayıcı konu olmuştur. Alanda oluşturulan bitkisel tasarım; yol ağaçlandırması, odak noktası oluşturma, gölgeleme, çim alanların tasarlanması, estetik vb. fonksiyonları göz önüne alınarak tasarlanmıştır (Çizelge 1).

Geçiş yollar boyunca hem gölge amaçlı ve hem yön göstermek için Acer platanoides, Acer negundo, Platanus orientalis gibi türler seçilerek, çim alanlar daha çok öğrencilerin rahatlıkla gezip, kitap okuyup ve arkadaşlarıyla vakit geçirebileceği şekilde tasarlanmıştır. $\mathrm{Bu}$ amaçlarla yapılan yerler, projedeki alanında daha çok Mediko meydanın kuzey batı kısmında ve Fen- Edebiyat Fakültesinin önünde önerilmiştir. Görsel amaçlı kullanılan bitkiler daha çok alanın giriş yolunda, Mediko meydanında, bina girişlerinde ve caminin avlusunda tasarlanmıştır. Genelde çiçek parterleri ile destekleyen sus havuzları estetiği artıran diğer bir tasarım elemanı olmuştur.

Mediko meydanında genellikle görsel ve form açısından farklı olan ve alanın diğer kısımlarında 
olmayan ağaçlar önerilmiştir ve böylece meydana vurgu ve odak yapılmasına neden olmuştur. Ayrıca meydanda önerilen ağaçların genelde gölgeli türlerden olmasına dikkat edilmiştir.

Mevsimsel değişimlere bağlı olarak alanın güneşlenme süresi ve yoğunluğu, yağış miktarı, açık günler sayısı da dikkate alınarak, bu değişimlere uygun bitkisel tasarımlar gerçekleştirilmiştir. Aynı zamanda alanda kullanılan bitkilerin estetik ve fonksiyonel özellikleri de ön planda tutulmuştur. Tasarımda kullanılan bitkilerin, Doğu Bölgesi florasında doğal olarak bulunan bitkiler ile bu bölgeye uyum sağlamış egzotik bitkilerden seçilmesine özen gösterilmiștir. Bölgenin doğal bitki örtüsünde bulunan; meșe ve alıç gibi türler tasarımda ağırlıklı olarak kullanılmıştır (Aslan vd. 2013).

Yağışlar nedeniyle kırılıp yürüme yoluna düșen dallar, yere dökülen yaprakları kaygan yüzeyler ve kirlilik oluşturabilecek türler, dikenler, zehirli ve kaygan meyveler üreten türler, yürüme yollarında tehlike arz edebilirler ve bundan dolayı dikkatli kullanılmaları gerekir. Dikenli bitkiler ile kaygan bir yüzey oluşturabilecek tohum ve meyve dökücü ağaç ve bitkiler, potansiyel tehlikeli bitkiler olduğundan yaya yollarından uzak tutulmuştur.

Çizelge 1. Bitkisel tasarımlarda kullanılan bitki türleri

\begin{tabular}{|c|c|c|c|}
\hline Latince İsim & Türkçe İsim & Latince İsim & Türkçe İsim \\
\hline Abies sp. & Göknar & Matricaria sp. & Papatya \\
\hline Acer negundo L. & Akçaağaç & Mentha piperita L. & Nane \\
\hline Aesculus hippocastanatum L. & At Kestanesi & Morus alba L. & Dut \\
\hline Amygdalus communis L. & Badem & Narcissus L. & Nergis \\
\hline Berberis $x$ thunbergia & Kadın Tuzluğu & Nepeta cataria L. & Kedi Nanesi \\
\hline Cactaceae & Kaktüs & Olea europaea L. & Zeytin \\
\hline Capsicum annum L. & Biber & Orchidaceae sp. & Orkide \\
\hline Carpinus betulus L. & Güren & $\begin{array}{l}\text { Pelargonium graveolens L'Her Ex } \\
\text { Ait. }\end{array}$ & Sardunya \\
\hline Castanea sativa Mill. & Kestane & Phoenix dactylifera L. & Hurma \\
\hline Cedrus libani A. Rich. & Lübnan Sediri & Picea orientalis (L.) Link. & Doğu Ladini \\
\hline Chamaerops excelsa Thunb. & Palmiye & Picea pungens 'Glauca' & Mavi Ladin \\
\hline Chamaerops humilis L. & Bodur Palmiye & $\begin{array}{l}\text { Pinus nigra Arnold ssp. } \\
\text { pallasiana (Lamb.) Holmboe }\end{array}$ & Anadolu Karaçamı \\
\hline Chrysanthemum L. & Kasımpatı & Pinus sylvestris L. & Sarıçam \\
\hline Citrullus lanatus L. & Karpuz & Platanus orientalis L. & Çınar \\
\hline Cornus alba 'Sibirica' & Süs Kızılcı̆̆ı & Populus nigra 'İtalica’ & Karakavak \\
\hline Corylus avellana L. & Fındık & Primula veris L. & Çuha Çiçeği \\
\hline Cotoneaster sp. & Dağ Muşmulası & Prunus avium L. & Kiraz \\
\hline Crataegus monogyna Jacq. & Alıç & Prunus cerasus L. & Vișne \\
\hline Cupressus sp. & Servi & Prunus domestica L. & Erik \\
\hline Cydonia oblonga Mill. & Ayva & Prunus laurocerasus L. & Karayemiș \\
\hline Diospyros kaki L. & Cennet Meyvesi & Prunus persica L. & Şeftali \\
\hline Eleagnus angustifolia L. & İğde & Punica granatum L. & Nar \\
\hline $\begin{array}{l}\text { Eriobotrya japonica (Thunberg) } \\
\text { Lindley }\end{array}$ & Yeni Dünya (Malta Eriği) & Pyracantha coccinea 'Nana' & Ateş Dikeni \\
\hline Euonymus japonica L. & Altuni Taflan & Pyrus communis L. & Armut \\
\hline $\begin{array}{l}\text { Euphorbia pulcherrima Willd. ex } \\
\text { Klotzsch }\end{array}$ & Atatürk Çiçeği & Quercus sp. & Meşe \\
\hline Ficus carica $\mathrm{L}$. & İncir & Ranunculus sp. & Düğün Çiç̧eği \\
\hline Ficus elastica Roxb. ex Hornem & Kauçuk & $\begin{array}{l}\text { Robinia pseudoacacia } \\
\text { 'Umbraculifera' }\end{array}$ & Top Akasya \\
\hline Fragaria vesca L. & Çilek & Robinia pseudoacacia L. & Yalancı Akasya \\
\hline Fritillaria imperialis L. & Ters Lale & Rosa hybrida L. & Gül \\
\hline Hedera helix L. & Sarmaşık & Rubus sp. & Böğürtlen \\
\hline Hyacinthus L. & Sümbül & Salix babylonica L. & Salkım Söğüt \\
\hline Hydrangea macrophylla L. & Ortanca & Syringa vulgaris L. & Leylak \\
\hline Juglans regia L. & Ceviz & Thuja orientalis L. & Mazı \\
\hline Juniperus sabina L. & Sabin Ardici & Tilia sp. & Ihlamur \\
\hline Laburnum anagyroides Med. & Sarı Salkım & Tulipa gerneirana L. & Lale \\
\hline Laurus nobilis L. & Defne & Ulmus glabra 'Huds' & Karaağaç \\
\hline Lonicera sp. & Hanımeli & Viburnum opulus L. & Kartopu \\
\hline \multirow[t]{2}{*}{ Malus communis L. } & Elma & Viola L. & Menekșe \\
\hline & & Vitis vinifera $\mathrm{L}$. & Asma \\
\hline
\end{tabular}




\section{Donatilar}

Proje tasarımlarında alan içerisinde kullanıcıların ihtiyaçlarını karşlayabilecek nitelikte oturma bankları, pergolalar, kameriyeler, gazebolar, bitki kasaları, çöp kutuları, su öğeleri, plastik objeler, aydınlatma birimleri, döşeme materyali, sulama sistemleri ve istinat duvarları gibi donatı elemanlarına yer verilmiştir.

\section{Oturma bankları}

Rekreaktif alanlarda, Mediko meydanın çevresinde, tören alanı çevresinde, gezinti yolları boyunca, spor alanların çevresinde, fakültelerin dış mekânlarının çevrelerinde, oturma ve dinlenme teraslarının bulunduğu alanlarda uygun yerlere ihtiyaç doğrultusunda oturma bankları yerleştirilmiştir. Oturma bankları iki, üç ve beşer kişinin oturabileceği ebatlarda tasarlanmıştır. Dinlenme alanlarında oturma banklarının yanında tekerlekli sandalyenin yanaşabileceği biçimde en az $120 \mathrm{~cm}$ boşluk bırakılmıștır.

\section{Pergolalar}

Proje alanı içerisinde gezinti yolları, seyir terasları, tören alanı çevresi ve rekreaktif alanlarının bulunduğu bölgelerde gölge ve dinlenme amaçlı yarı açık mekânlar olarak pergolalar kullanılmıştır.

\section{Kameriye ve Gazebolar}

Güneydeki giriş yolun sağ kısmında otopark alanın üst bölgesinde hakim manzara noktalarının bulunduğu alanlarda ve bazı projelerde alanın güney doğusunda ağaçlık alanların bulunduğu bölgede kullanıcıların dinlenme ve eğlenme ihtiyaçlarını karşılamak amacı ile alanda kameriye ve gazebo tasarlanmıştır.

\section{Bitki kasaları}

Malatya kentinde doğal olarak yetişmeyen egzotik bitkilerin içinde bulunduğu, kış aylarında iç mekânda da kullanılabilecek tekerlekli sisteme sahip donatı elemanları olarak tasarlanmışlardır. Tören alanı gibi sert zeminin yoğun olarak bulunduğu alanlarda sert zeminin yoğun etkisini ortadan kaldırmak, oturma mekânlarını sınırlamak, alan kullanıcılarını yönlendirmek ve alana hareketlik katmak amacı ile mekâna yerleştirilmişlerdir.

\section{Çöp kutuları}

Alan içerisinde değişik boyut ve ebatlarda (engelli bireyleri göz önüne alınarak) çevre sağlı̆̆ını ve temizliğini sağlamak amacı ile çok sayıda çöp kutusu kullanılmıştır. Çöp kutuları, yaralanmalara neden olmayacak malzemelerden seçilmiş, kontrast renkli ve tek elle kullanılabilecek şekilde kapaklı olmuştur. Çöp kutuları yaya hareketine engel olmayacak şekilde yaya kaldırımı kenarında bordür taşına en az $40 \mathrm{~cm}$ uzaklığında ve en az $90 \mathrm{~cm}$, en çok $120 \mathrm{~cm}$ yüksekliğe monte edilmesi önerilmiştir.

\section{Su öğeleri}

Proje alanına boyut, derinlik ve çekicilik kazandırmak amacıyla hareketli ve durgun olmak üzere çeşitli su öğeleri tasarlanmıştır. Projelerde tasarlanan su öğeleri farklı alanlarda; Mediko meydanında ve camii avlusunda sus havuzu, güney girişinde kaskatı su öğesi ve Kıbrıs meydanında fıskiyeli havuz tasarlanmıştır.

\section{Aydınlatma birimleri}

Gündüz ve gece değişimleri alan içerisindeki akademik, idari ve öğrenci yerleşimlerinin güvenliği açısından oldukça önemlidir. Alan içindeki sosyal mekânların gün içerisinde her zaman kullanılması mümkün olmayacağından bu mekanlar gündüz gece değişimleri göz önünde bulundurularak tasarlanmıştır. Aydınlatma elemanı olarak yüksek, alçak ve spot aydınlatma armatürleri kullanılmıştır. Alan içerisinde özel niteliği olan bitkilerde ve su öğelerinin çevresinde gibi özel bölgelerde aydınlatma elemanları kullanılmıştır.

Aydınlatma özellikle rampa ve merdiven girişleri gibi potansiyel tehlike taşıyan alanlarda engelli kişiler için güvenlik açısından göz önüne tutulmuştur. Aydınlatma engellilerin ihtiyaçları göz önünde bulundurularak sabit elemanlar kullanılarak planlanmıştır. Az gören kişiler için ışık şiddetinin artırılması mekânları algılamaları açısından faydalı olabilir. Birçok aydınlatma standardı yetişkin bir insanın ayaktayken göz hizasının yüksekliği ön görülerek belirlenmiştir. Tekerlekli sandalye kullanıcılarının göz hizası yüksekliği yaklaşık $1.19 \mathrm{~m}$ olduğu için mevcuttaki aydınlatma elemanları tekrardan revize edilmiştir.

\section{Bankamatikler}

Mediko meydanın güney doğusunda mevcutta bulunan 4 adet bankamatik vardır. Gün içerisinde bu bankamatikler aktif olarak kullanılmaktadır. Meydanı daha sakin ve huzurlu ortama dönüştürmek için bazı projelerde tasarımcılar, bu bankamatiklerin yer değişimi kanaatine varmışlardır. Bankamatiklerin yeni kullanım yerleri ise sert beton zemine sahip olan alanlar Kıbrıs Meydanı gibi alanlar olmuştur. 


\section{Döşeme materyali}

Malatya kent karakterine ve iklim özelliklerine uygun döşeme malzemeleri seçilerek, tasarımda kullanılan desenler yardımı ile kullanıcılar üzerinde hoş bir etki oluşturmak, onları yönlendirmek, renk tonları ile rahatlatıcı, sakinleştirici, dinlendirici bir etki sağlamak amacı ile döşeme materyali kullanılmıştır. Farklı engelli grupları için; ses, renk, aydınlatma, malzeme ve doku yapısı değiștirilerek yaya yolunda yönlendirme yapılmıştır.

\section{Sonuçlar ve Tartışma}

Üniversiteler eğitim- öğretim sağlamanın yanında öğrencilere, eğitimcilere, çalışanlarına ve bulunduğu bölgede muasır yaşam tarzı ve ortamlarını temsil etmelidir. Üniversiteler sanatsal, kültürel, sosyal ve sportif etkinlikler için uygun ortamlar ve tesisler oluşturularak kullanıcıların kendilerini geliștirme ve sosyal etkinliklere katılarak sosyalleşmelerine zemin hazırlamaktadır. Diğer kentsel alanlarda yapılan planlamalar gibi üniversite kampüslerinin planlanması da kentsel tasarım ölçeğinde değerlendirilmelidir.

Günümüzde oluşturulan üniversite kampüslerinde düzenli tasarım yapılması önemli konulardan olmuştur ancak yeni bölüm, faküllerin ve tesislerin yapılmasıyla kampüslerin zaman gittikçe büyümesi ve genişlenmesiyle Üniversitelere ait akademik ve sosyal birimler arasındaki bağlantı noksanlığı sonradan ortaya çıkan sorunların başına gelmektedir. Üniversite kampüsündeki alanlar arasında ortaya çıkan kopukluklar ortak kullanım alanlarının Herkes tarafından kullanılmamasına neden olmaktadır. $\mathrm{Bu}$ nedenle dinamik bir yapıya sahip üniversitelerin, geçen süre içerisinde gelişme ve büyümelere açık olarak tasarlanmasıdır. Bunun yanında kampüs planlamaların bütüncül ve gelişebilir bir yaklaşımın olması gerekmektedir. Üniversiteler fiziksel olarak bulunduğu kenti en iyi biçimde temsil etmelilerdir. Nitekim bu eğitim kurumları bölgenin sosyo-kültürel ve ekonomik açıdan geleceğini etkileyen önemli unsurdur.

İnönü üniversitesi eğitim- öğretim hayatına başlamasından itibaren girdikçe büyümekte ve gelişmektedir. Kampüs alanı gelişmeye müsait olmasına rağmen bazı ortak kullanım alanların sonradan yapılması ve nüfusun çoğalmasıyla beraber mekânlar arasında bağlantı sıkıntısı ortaya çıkmıştır. $\mathrm{Bu}$ alanların biri ise üniversitenin sosyo-kültürel merkezi sayılan Mediko Meydanı olarak gözlenmiştir. $\mathrm{Bu}$ alanın hemen yanında inşaatı bitmekte olan camii nedeniyle alanın yeniden düzenlenmesi, bağlantıların tasarlanması ve sosyokültürel mekânların kullanıcı isteklerine göre planlaması, Peyzaj Mimarlığı Bölümü Proje III kapsamında ele alınması gereği söz konusu olmuştur. Kampüsün bir parçası seçilen proje alanın tasarlanmasında kampüsün bütün yapısal ve mekânsal özellikleri göz önüne alınmıştır. Çalışma süresince alanda toplanmış bilgi, sörvey ve değerlendirmeler sayesinde problem tanımı, ihtiyaç listesinin belirlenmesi, alan analizi ve tasarım çalışması gerçekleștirilmiştir. Peyzaj tasarım projesinde alanda, bütün kullanıcılara (engelli olan bireyler dahil) uygun olan aktiviteler, bağlantılar, yapısal ve bitkisel alanlar tasarlanmıştır.

\section{Teşekkürler}

Bu çalışma, İnönü Üniversitesi, Güzel Sanatlar ve Tasarım Fakültesi, Peyzaj Mimarlığı Bölümü 20182019 Güz dönemi, atölye çalışması 3 sınıf Proje III dersi kapsamında öğretim üyeleri eşliğinde yapılmıştır.

\section{Kaynaklar}

Aslan, F., Kaya, L. G., Yılmaz, B., \& Atilla, A. T. İ. K. 2013. Malatya Kent Halkının Dış Mekan Bitki Tercihlerinin Belirlenmesi Üzerine Bir Araştırma. Social Sciences, 8(1): 33-49.

Altuğ, İ., Gülgün, B., 2005. Kentsel Dış Mekanlara Yönelik Yapısal Uygulamalardan; Drenaj, Sulama, Aydınlatma Ve Döşeme Çalışmalarının Konak Meydanı Ve Çevresi Düzenlemesi Örneğinde İrdelenmesi. Ege Üniv. Ziraat Fak. Derg., 42(3):183194.

Atabeyoğlu Ö 2014. Sosyal Bilimler Meslek Yüksekokulu Kampusu peyzaj tasarım ve uygulama çalışması. Artium, 2(1).

Atabeyoğlu Ö 2004. Erzurum Kentindeki Resmi Kurum Ve Lojman Bahçelerinin Peyzaj Mimarlığ Açısından İncelenmesi. Atatürk Üniversitesi Fen Bilimleri Enstitüsü Yüksek Lisans Tezi. 
Ateș, O., Sabaz, M., 2013. İnönü Üniversitesi Merkez Kampüsü'nde Arboretum Park Oluşturulmasına Yönelik Bir Araştırma. İnönü Üniversitesi Sanat ve Tasarım Dergisi, 3(8), 123-139.

Aydin, D., ve Ter, U. 2008. Outdoor space quality: Case study of a university campus plaza. International Journal of Architectural Research: ArchNet-IJAR, 2(3), 189-203.

Bilgin, A., 2006, Doğu Akdeniz Bölgesi ve Çevresinde Üniversite Kampüs Planlaması Üzerine Bir İnceleme, Yüksek Lisans Tezi, Çukurova Üniversitesi Fen Bilimleri Enstitüsü, Adana.

Çınar, E., 1998, Üniversite Kampüs Planlaması ve Tasarımı Üzerine Bir Araștırma, Yüksek Lisans Tezi, İtü Fen Bilimleri Enstitüsü, İstanbul.

Coulson, J., Roberts, P., \& Taylor, I. 2017. University trends: Contemporary campus design. Routledge.

Çorbacı, Ö., L, Gülez, S., Topay, M., 2005. Zkü Merkez Kampüsü Isı Merkezi Yolu Ve Çevresi Peyzaj Ve Rekreasyon Projesi. Zkü Bartın Orman Fakültesi Dergisi, Cilt:7 Sayı:7.

Dober R 2000. Campus Landscape: Functions, Forms, Features.John Wiley \& Sons, Inc. Printed in United States Of America, Isbn: 0-471-35356-6, 259 P., U.S.A.

Erkman U 1990. Büyüme ve Gelişme Sorunları Açısından Üniversite Kampüslerinde Planlama ve Tasarım Sorunları, İtü Mimarlık Fakültesi Baskı Atölyesi, İstanbul

Erçevik, B., Önal, F., 2011. The Usage of Social Areas in University Campus Systems. Megaron/Yıldız Technical University, Faculty of Architecture EJournal, 6(3), 151-161.

Erçevik B 2008. Üniversitelerde Sosyal Mekan Kullanımlarının İncelenmesi: Kent Üniversitesi, Kent İçi Ve Kent Dışı Kampüsler, Yayınlanmamış Yüksek Lisans Tezi, Yıldız Teknik Üniversitesi, Fen Bilimleri Enstitüsü, İstanbul.
Ertekin M., Lütfü Çorbacl, Ö., 2010. Üniversite Kampüslerinde Peyzaj Tasarımı (Karabük Üniversitesi Peyzaj Projesi Örneği), Kastamonu Üni., Orman Fakültesi Dergisi, 10 (1): 55-67.

Jie, Z. H. U. 2008. Study on the Design of Outdoor Space on University Campus [J]. Chinese Landscape Architecture, 4.

Karaaslan M 1979. Üniversite Kampüs Planlaması, Edirne Müh.-Mim. Akademisi, Edirne

Karataş Ş, 2016. Malatya İli Florası, İnönü Üniversitesi / Fen Bilimleri Enstitüsü / Biyoloji Anabilim Dalı, Doktora Tezi.

Kuyrukçu Z 2012. Kampüslerde Fiziksel Değişim Üzerine Bir Araştırma: Selçuk Üniversitesi Alaeddin Keykubat Kampüsü Örneği Yüksek Lisans Tezi, Selçuk Üniversitesi Fen Bilimleri Enstitüsü.

Sönmezler K 1995. Üniversiteler, Yüksek Lisans Tezi, Mimar Sinan Üniversitesi Fen Bilimleri Enstitüsü.

Lau, S. S. Y., Gou, Z., ve Liu, Y. 2014. Healthy campus by open space design: Approaches and guidelines. Frontiers of Architectural Research, 3(4), 452-467.

Schmertz, M. F. (Ed.). 1972. Campus planning and design. McGraw-Hill.

Turner P. V 1995. "Campus" An American Planning Tradition, The Mit Pres Cambridge, Massachusets And London

Türeyen M 2002. Yükseköğretim Kurumları - Kampuslar, Tasarım yayın grubu, İstanbul.

Turcan Y 1996. Tarihsel Süreç İçinde Yükseköğretim Yapılarının Mekansal Analizi, Doktora Tezi, Karadeniz Teknik Üniversitesi, Trabzon

Turgut H 2011. Erzurum Büyükșehir Belediye Binası Ön Bahçe Peyzaj Tasarım Çalışmasının Tasarım İlkeleri Bağlamında Değerlendirilmesi. Artvin Çoruh Üniversitesi Orman Fakültesi Dergisi,12 (2): 185198, Artvin. 
Yılmaz B 1998. Bartın Kenti Açık ve Yeşilalan Sisteminin Saptanması Üzerine Bir Araştırma, Peyzaj Yüksek Mimarlığı Tezi Z.K.Ü. Fen Bilimleri Enstitüsü Peyzaj Mimarlığı Anabilim Dalı, Bartın.
URL 1. http://www.inonu.edu.tr/tr/14/m (Erişim tarihi:17.03.2019). 